\title{
IN SIGNUM BENEVOLI AFFECTUS I. SEVEN ALBUM INSCRIPTIONS BY MENASSEH BEN ISRAEL
}

\author{
Ferenc Postma and Arian Verheij \\ Independent scholars, The Netherlands
}

In the academic circles of seventeenth-century Europe, it was fashionable to own an album amicorum (German: Stammbuch), a pocket book in which one's friends would enter proverbs, short poems, dedications and the like. Not only personal friends, but specifically professors and public personalities as well were often invited to 'write a few words' in honour of the album's owner - whose purpose it was to collect and boast as many of these contacts as possible, in order to build his personal network in the Republic of Letters.

It is therefore only logical that also some so-called album inscriptions by Menasseh ben Israel (1604-1657), rabbi, printer, diplomat, ${ }^{1}$ and one of the leading Jewish intellectuals in his day, should have survived. In fact, at this point we have collected seven such inscriptions, spanning a period of ten years (1645-1655) and all written in Amsterdam, which we present below. ${ }^{2}$

\footnotetext{
${ }^{1}$ C. Roth, A Life of Menasseh ben Israel. Rabbi, Printer, and Diplomat (Philadelphia 1934).

${ }^{2}$ For this article we contacted the University Libraries of Amsterdam and Leyden; the Bibliotheca Philosophica Hermetica, Amsterdam; the Koninklijke Bibliotheek, The Hague; the British Library, London; the Universitätsbibliothek, Bochum; the Staatsund Universitätsbibliothek, Hamburg; the Herzog August Bibliothek, Wolfenbüttel; the Württembergische Landesbibliothek, Stuttgart; the Öffentliche Bibliothek der Universität Basel; the Vadianische Sammlung, St. Gallen; the Kongelige Bibliotek, Copenhagen; the Kungliga Biblioteket, Stockholm; the Széchényi National Library, Budapest; the Library of the Academia România, filiala Cluj, Cluj-Napoca; the Library of the Protestáns Teológiai Intézet, Cluj-Napoca. We also consulted the following two databases: IAA 'Inscriptiones Alborum Amicorum, Database of 16-18th century album amicorum entries of Hungarian relevance' by M. Latzkovits, University of Szeged (http://susu.cs.jgytf.u-szeged.hu/`latzkovits); RAA 'Repertorium Alborum Amicorum, Internationales Verzeichnis von Stammbüchern und Stammbuchfragmenten in öffentlichen und privaten Sammlungen' by W.W. Schnabel, University of Erlangen (http://www.raa.phil.uni-erlangen.de). Cf. K. Thomassen, ed., Alba Amicorum - Vijf eeuwen vriendschap op papier gezet: Het Album Amicorum en het Poëziealbum in de Nederlanden (Maarssen/'s-Gravenhage 1990) 173-175, for an extensive bibliography on alba amicorum. Two inscriptions by Menasseh were published earlier (Meisner, cf. n. 6, Arnold, cf. n. 17), one is mentioned in a catalogue (Gerhard, cf. n. 12), the other four are now published in English for the first time (cf. in Dutch, F. Postma and A.J.C. Verheij, 'Vijf
}

(C) Koninklijke Brill NV, Leiden, 2009

ZUTOT 6.1

Also available online - brill.nl/zuto 
The albums in which Menasseh is now known to have written a 'few words' belonged to Christian scholars of philosophy and theology from Germany, Hungary, Switzerland and the Low Countries, most of whom came to Amsterdam as part of their peregrinatio academica - an academic journey during which they would visit several European universities.

A detailed analysis of Menasseh's Umfeld as an inscriber (who were the others to contribute to these specific albums, and what does that tell us about how the albums' owners saw Menasseh?) is beyond the scope of this article. Also, the results could never be conclusive, given the small number of inscriptions that we have. ${ }^{3}$ It is our impression, however, that as far as Amsterdam is concerned, our seven album owners were particularly interested in meeting the spiritual and intellectual leaders of that city. One name that recurs in several albums is that of Stephanus Curcellaeus (Etienne de Courcelles, 1586-1659), the wellknown professor at the Remonstrant Seminary of Amsterdam.

The seven inscriptions conform to the two-part structure that is often found in alba. The first part contains proverbs and maxims taken mostly from Jewish traditional literature, starting out with a Hebrew quotation from Pirqe Avot, in square script. In the inscription dedicated to Christoph Arnold (see p. 41) this is the only element of this part. Then follows a more general and succinct saying or proverb. In four cases we have an Aramaic saying, written in rabbinic script. One is again a quotation from Pirqe Avot (Johan Albert Zaunschliffer, p. 44), the other three comprise Hillel's Golden Rule from Shabbath 31a (Johann Meisner, István Pauli, Benedek Árkosi, pp. 37, 42 and 45 resp.). Two albums (Johann Ernst Gerhard, Johann Zollikofer, pp. 39 and 47 resp.) have Latin maxims. Meisner, the earliest of these inscriptions, has an additional proverb in Arabic.

The second part of each inscription is a Latin dedication testifying to Menasseh's esteem for the album's owner, with reference to the quotations ('few words') of the first part. It closes with Menasseh's signature, which in most cases (not in the inscriptions dedicated to Gerhard and Arnold, both from June 1650) is syntactically part of the dedication, and the place and date of the inscription. The year of the date is

album-inscripties van Menasseh ben Israel - Een eerste kennismaking', in Alef Beet 11/2 (2001) 23-32. After the completion of this article, we discovered one further inscription by Menasseh which we hope to publish in due course.

${ }^{3}$ Indeed, Menasseh's surviving autographs are very rare (cf. B. de Haas, 'Het UvAproject "Menasseh Ben Israël",' in Alef Beet 8/1 (1998) 22-25. A. Offenberg, Menasseh ben Israel (1604-1657): Een biografische schets (Amsterdam 2000). Roth, A Life, 159, suggests that Menasseh disliked the practice of album-keeping. 
Jewish, except in Meisner, whereas day and month are expressed in the Christian calendar. Curiously, the earliest and latest of our Latin dedications (Meisner, Zollikofer) are almost identical in wording. The inscriptions are presented here in chronological order.

Inscription Dedicated to Fohann Meisner, Amsterdam, April 15, 1645

Johann Meisner was born in Torgau on April 4, 1615, into a Lutheran family. A Wittenberg Magister, he travelled to France, passing through the Low Countries (i.a. Leyden). In Amsterdam he paid a visit to Menasseh, bringing a message from Abraham von Franckenberg (1593-1652), a 'disciple' of Jacob Böhme. ${ }^{4}$ He became a professor of Theology at Wittenberg University, where he died in $1681 . .^{5}$ The few remains of his album amicorum are kept in the State and University Library, Hamburg [Sup. ep. 28]. Menasseh's inscription is on fol. 159r. It differs from the other ones presented here in that it has three proverbs, and a completely Christian dating. ${ }^{6}$

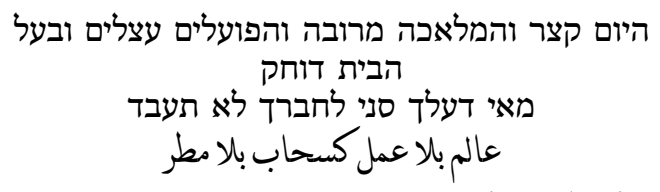

Virtute doctrinaque ornatissimo D. FOANNI MEISNERO

Amstelod. M D CXLV

15. Aprilis in signum benevoli affectus pauca haec lubens scribebat Menasseh ben Israel

[Hebr.] 'The day is short and the task is great and the labourers are idle [and the wage is abundant] ${ }^{7}$ and the master of the house is urgent.' (Pirqe Avot 2.15). ${ }^{8}$

4 Roth, A Life, $158 f$.

${ }^{5}$ Chr.G. Jöcher, Allgemeines Gelehrten-Lexicon (Leipzig 1750, 1751; reprint Hildesheim 1961) III, 384f.; RGG, Die Religion in Geschichte und Gegenwart, 4th Edn., V, 996f. (1684 acc. to RGG, 3rd Edn., IV, 832f.).

6 The inscription was published (with תעשה instead of, and dated April 25) by M. Grunwald in Monatsschrift für Geschichte und Wissenschaft des Fudenthums 41 [N.F. 5] (1897) 573. Basing himself on this publication, Roth, A Life, 159, reads the inscription as evidence of unwillingness, 'grim humor' and 'sarcasm' on Menasseh's part.

7 The words, 'and the wage is abundant' (והשכר הרבה), are lacking in Menasseh's text.

${ }^{8}$ Transl. H. Danby, The Mishnah. Translated from the Hebrew with Introduction and Brief Explanatory Notes (Oxford 1933) 449. 

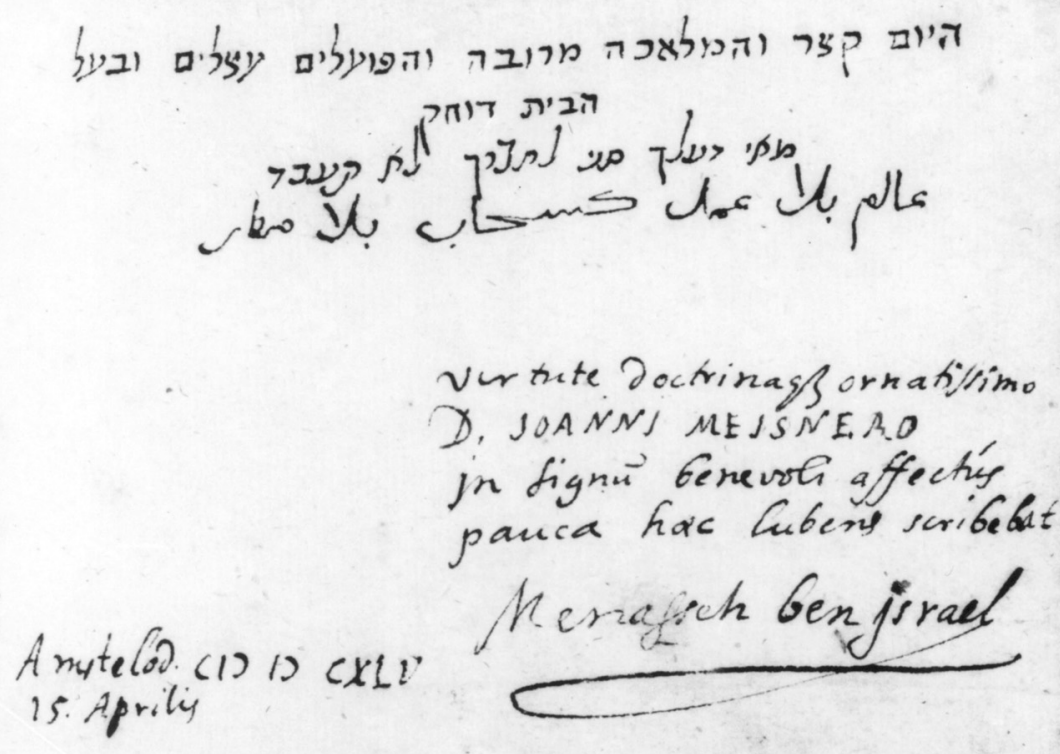

Inscription for Johann Meisner (courtesy: the Staats- und Universitätsbibliothek, Hamburg)

[Aram.] 'What is hateful to you, do not to your neighbour' (Shabbath $31 \mathrm{a}) .^{9}$

[Arab.] 'A scholar without doings is like a cloud without rain.' 10

9 Transl. H. Freedman, Hebrew-English Edition of the Babylonian Talmud. Shabbath. Translated into English with Notes, Glossary and Indices by H. Freedman. Under the Editorship of I. Epstein. Foreword by J.H. Hertz. Introduction by the Editor (London/ Jerusalem/New York 1972).

${ }_{10}$ Perhaps Menasseh knew this Arab proverb from Erpenius (Th. Erpenius, Locmani sapientis fabulae et selecta quaedam Arabum adagia. Cum interpretatione Latina \& notis, Amsterdam 1636, part of Grammatica Arabica; ab autore emendata $\mathcal{E}^{\circ}$ aucta. Cui accedunt Locmanni fabulae et adagia quaedam Arabum. Ab eodem autore cum Latina versione pridem edita, at nunc vocalibus $\mathbb{E}^{\circ}$ notis orthographicis illustrata, Amsterdam 1636), where it is quoted as adagium LXXXIX on p. 58, with the Latin rendering Doctus sine opere, ut nubes est sine pluvia. A similar כל כל תורה שאין עמה מלאכה סופה בטלה וגוררת עון :2.2 'all study of the Law without [worldly] labour comes to naught at the last and brings sin in its train', transl. Danby, The Mishnah, 447 (cf. A. Houtman, 'Studie en ambacht. Een lezing van Avot 2:2,' in Alef Beet $11 / 1$ (2001) 28-33). A collection of Hebrew sayings is J. Buxtorf the younger, Florilegium hebraicum, continens Elegantes sententias, Proverbia, Apophthegmata, Similitudines (...) (Basle 1648), containing Hillel's Golden Rule, rendered as Quod exosum tibi, proximo tuo ne feceris $(236,358)$. 
[Dedication] For mister Johann Meisner, so well endowed with virtue and learning, Menasseh ben Israel with pleasure wrote these few words, as a token of his well-wishing affection.

\section{Inscription Dedicated to Fohann Ernst Gerhard, Amsterdam, Fune 11, 1650}

Johann Ernst Gerhard the elder was born in Jena on December 15, 1621, into a Lutheran family. He read Oriental languages, Philosophy and Theology at several universities. As a Magister he made his academic tour, and in the Netherlands he visited the universities of Groningen, Franeker, Utrecht and Leyden. In 1652 he became a professor of History and later of Theology at the University of Jena, where he died on February 24, 1668. ${ }^{11}$ Gerhard's album amicorum is kept in the private collection of the late M. Hertzberger. ${ }^{12}$ Among the other inscribers is Stephanus Curcellaeus. Menasseh's inscription is on fol. 89r.

\section{הכל צפוי והרשות נתונה ובטוב

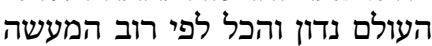

Spe et patientia

Clarissimo et eruditissimo

D. M. Johanni Ernesto Gerar-

do in signum amicitiae scripsi

Amstelodami XI. Fun. An. $\underline{5410}$

Menasseh ben Israel

[Hebr.] 'All is foreseen, but freedom of choice is given; and the world is judged by grace, yet all is according to the excess of works' (Pirqe Avot 3.16). ${ }^{13}$

[Lat.] With hope and patience. ${ }^{14}$

${ }^{11}$ Jöcher, Allgemeines Gelehrten-Lexicon, II, $951 \mathrm{f}$.

12 Courtesy the Hertzberger family. It is mentioned in L. Fuks and M.H. Gans, Menasseh Ben Israel, 1604-1657. Catalogus van de tentoonstelling georganiseerd door het Genootschap voor de Foodse wetenschap en het foods Historisch Museum (Amsterdam 1957) 24, no. XXXVI. It was displayed at the exhibition 'Baruch de Spinoza, 1677-1977. Werk und Wirkung [vom 21. Februar bis zum 30. April 1977]' in the Herzog August Bibliothek, Wolfenbüttel, showing the inscription by Menasseh ('einer der Lehrer Spinozas'). Cf. HAB, Ausstellungskataloge der Herzog August Bibliothek, Nir. 19 (Wolfenbüttel 1977) 34 (no. 21).

13 Transl. Danby, The Mishnah, 452.

${ }_{14}$ We have not been able to determine whether this really is a proverb. Separately, the words may have been taken to refer to virtues. A completely unrelated German album from 1680 contains an inscription saying: 'Durch Hoffnung und Geduld, erlangt man Gottes Huld' (A. Buck and M. Bircher, eds., Respublica Guelpherbytana, Wolfenbïtteler Beiträge 


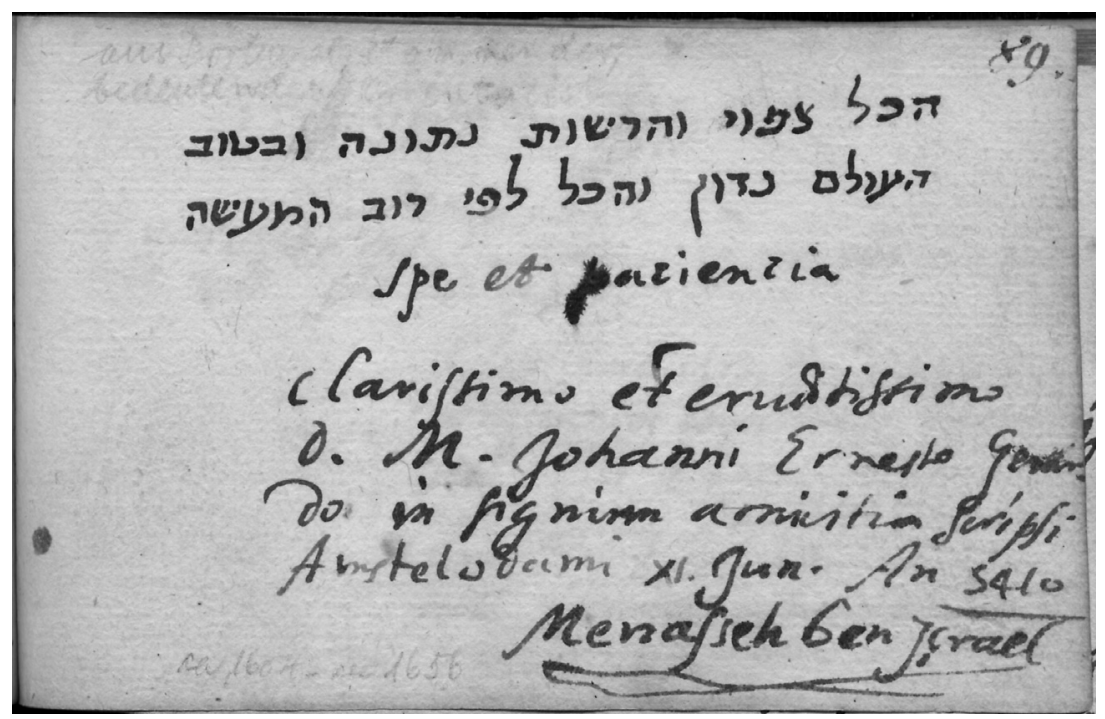

Inscription for Johann Ernst Gerhard (courtesy: the Hertzberger family)

[Dedication] For the very enlightened and learned Magister Johann Ernst Gerhard I wrote (the above words) as a token of friendship.

Inscription Dedicated to Christoph Arnold, Amsterdam, June 14, 1650

Christoph Arnold was born in Hersbrück near Nuremberg on April 12, 1627, into a Lutheran family. He read Theology and Philosophy at the University of Altdorf, where he obtained the degree of Magister in 1649. His academic tour through the Netherlands (Groningen, Utrecht, Leyden) and Great Britain lasted from 1649 till 1652. ${ }^{15}$ Arnold became a professor of Greek, Rhetoric, Poetry and History at the Aegidien-Gymnasium of Nuremberg, where he died in 1685. His album amicorum is kept in the British Library, London (MS Egerton 1.324). Among the other inscribers is the English poet John Milton $(1608-1674) .{ }^{16}$ Menasseh's inscription is on fol. 26r. ${ }^{17}$

zur Renaissance- und Barockforschung. Festschrift für Paul Raabe, [Chloe, vol. 6] [Amsterdam 1987] 324f.). Cf. also below, Zollikofer.

15 Arnold is mentioned among 'Menasseh's friends' by Roth, A Life, 168.

${ }^{16}$ F.J.M. Blom, Christoph \& Andreas Arnold and England. The travels and book-collections of two seventeenth-century Nurembergers, Ph.D. thesis, Nijmegen (Enschede 1981) 25. Cf. also below, Zollikofer.

17 The inscription is mentioned (and dated 1651) in Blom, Christoph \& Andreas Arnold, 


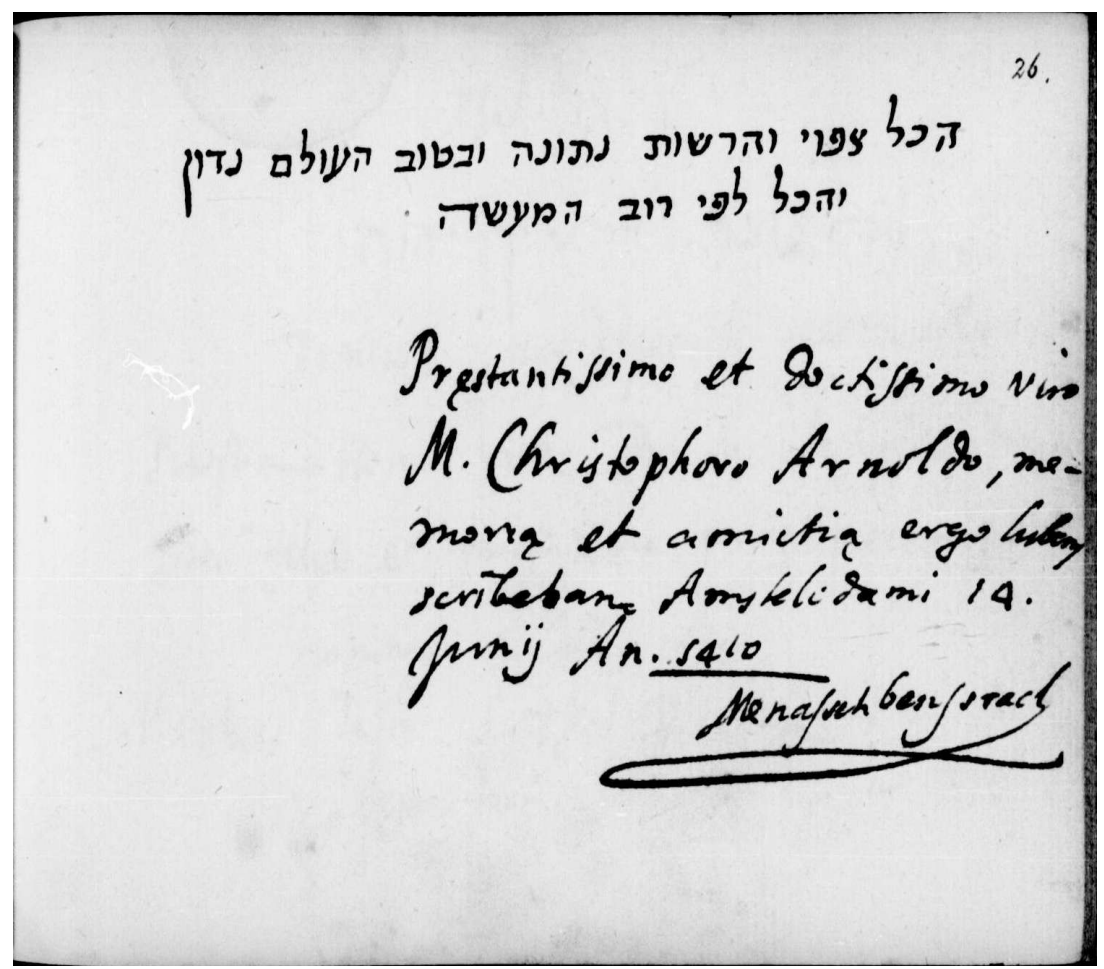

Inscription for Christoph Arnold (courtesy: the British Library, London)

הכל צפוי והרשות נתונה ובטוב העולם נדון

והכל לפי רוב המעשה הונה העוב

Praestantissimo et doctissimo viro M. Christophoro Arnoldo, memoriae et amicitiae ergo lubens scribebam Amstelodami 14. Junï An. $\underline{5410}$

Menasseh ben Israel

[Hebr.] 'All is foreseen, but freedom of choice is given; and the world is judged by grace, yet all is according to the excess of works' (Pirqe Avot 3.16). ${ }^{18}$

23. A photograph, contributed by Jan-Wim Wesselius, was published as an appendix to H.P. Salomon, 'Menasseh ben Israel, Saul Levi Mortera et le "Testimonium Flavianum",' in Studia Rosenthaliana 25 (1991) 31-41.

18 Transl. Danby, The Mishnah, 452. 
[Dedication] For the outstanding and most learned Magister Christoph Arnold, I wrote (the above words) with pleasure for the sake of remembrance and friendship.

\section{Inscription Dedicated to István Pauli, Amsterdam, October 1, 1653}

István Pauli (or Paulini, and also known as István Pauli Stennarius) was probably born in 1631 in the town of Kolozsvár (now Cluj-Napoca, Romania) into a Unitarian family. ${ }^{19}$ Together with Benedek Árkosi (see below), he read Philosophy and Theology in Frankfurt/Oder (1651), Leyden (1653), and elsewhere. He was appointed professor of Theology at the Unitarian College of Kolozsvár in 1661, where he died November 5, 1672. ${ }^{20}$ Pauli's album amicorum is kept in the Library of the Romanian Academy of Sciences, Cluj-Napoca [Ms. U. 1]. Among the other inscribers are Stephanus Curcellaeus, and Arnoldus Poelenburg (one of Curcellaeus' students at the Remonstrant Seminary of Amsterdam). The inscription by Menasseh is on fol. $55 \mathrm{r}$.

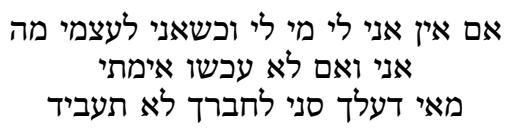

Amsteloda-

mi 1. Octob.

An. $\underline{5414}$
Praestantissimo ac eruditissimo viro, D. Stephano Paulini philosophiae ac Theologiae studioso, in signum benevolentiae gravia pauca haec lubens scribebat

Menasseh ben Israel

[Hebr.] 'If I am not for myself who is for me? and being for mine own self what am I? and if not now, when?' (Pirqe Avot 1.14). ${ }^{21}$

${ }^{19}$ Unitarianism, denying the Trinity, was mostly regarded as a heresy by mainstream Christendom.

${ }^{20}$ G. Kathona, 'Erdélyi unitárius tanulók külföldön 1711-ig' (Unitarian Students from Transylvania Abroad Until the Year 1711), in Keresztény Magvetó 85 (1979) 30-39, esp. 34, M. Szabó and S. Tonk, Erdélyiek egyetemjárása a korai újkorban, 1521-1700 (Students from Transylvania at Western European Universities during the Early Modern Period, 1521-1700), Fontes Rerum Scholasticarum, IV (Szeged 1992) 264 (nr. 2649).

${ }^{21}$ Transl. Danby, The Mishnah, 447. 


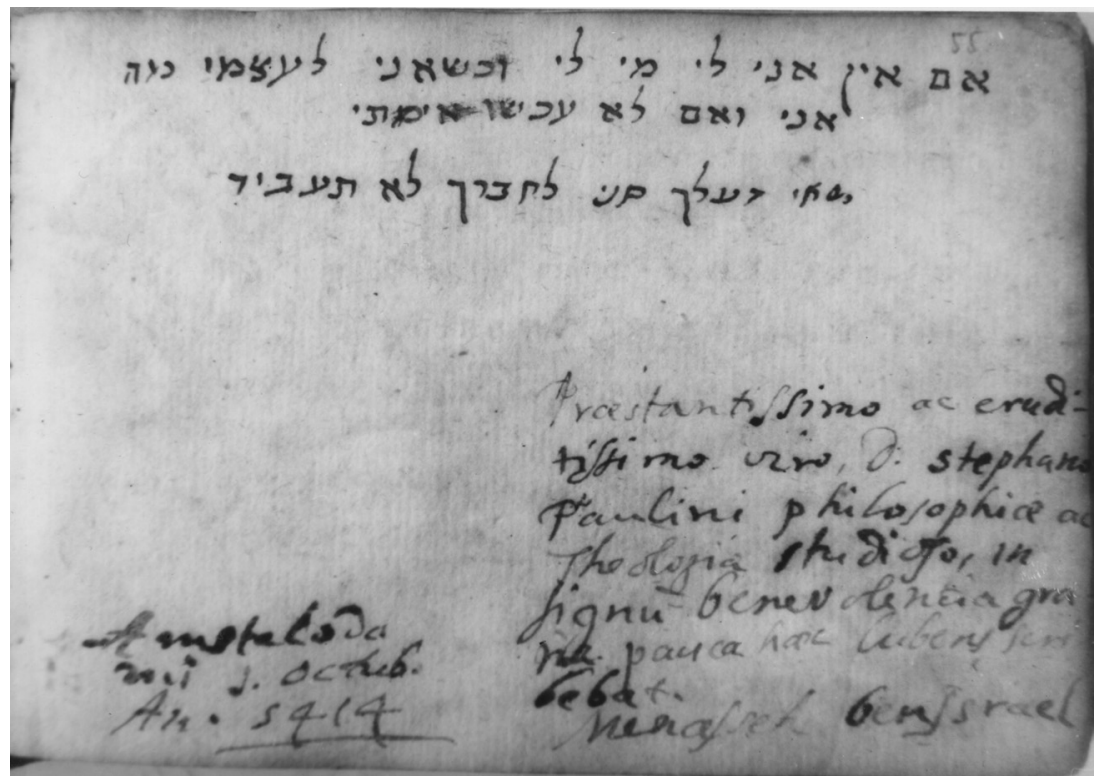

Inscription for István Pauli (courtesy: the Library of the Academia România, filiala Cluj, Cluj-Napoca)

[Aram.] 'What is hateful to you, do not to your neighbour' (Shabbath $31 \mathrm{a}) \cdot{ }^{22}$

[Dedication] For the outstanding and most learned mister István Paulini, a student of Philosophy and Theology, Menasseh ben Israel with pleasure wrote these few serious words, as a token of his well-wishing.

Inscription Dedicated to Fohan Albert Zaunschliffer, Amsterdam, April 27, 1654

Johan Albert Zaunschliffer ${ }^{23}$ was born in Amersfoort in 1634. From 1651 to 1655, he read Theology and Oriental Languages in Groningen, where his father was then a minister. He himself became a Reformed minister as well in 1657, eventually in Oostzaan, where he died 1678. ${ }^{24}$ Zaunschliffer's album amicorum is kept in the University Library of Amsterdam [Ms. XXV C 27]. Menasseh's inscription is on fol. 74r.

\footnotetext{
${ }^{22}$ Transl. Freedman, Babylonian Talmud.

${ }^{23}$ Roth, A Life, 168: 'Albrecht Zaunschleifer'.

${ }_{24}$ F.A. van Lieburg, Repertorium van Nederlandse hervormde predikanten tot 1816. I: Predikanten; II: Gemeenten (Dordrecht 1996) I, 216.
} 


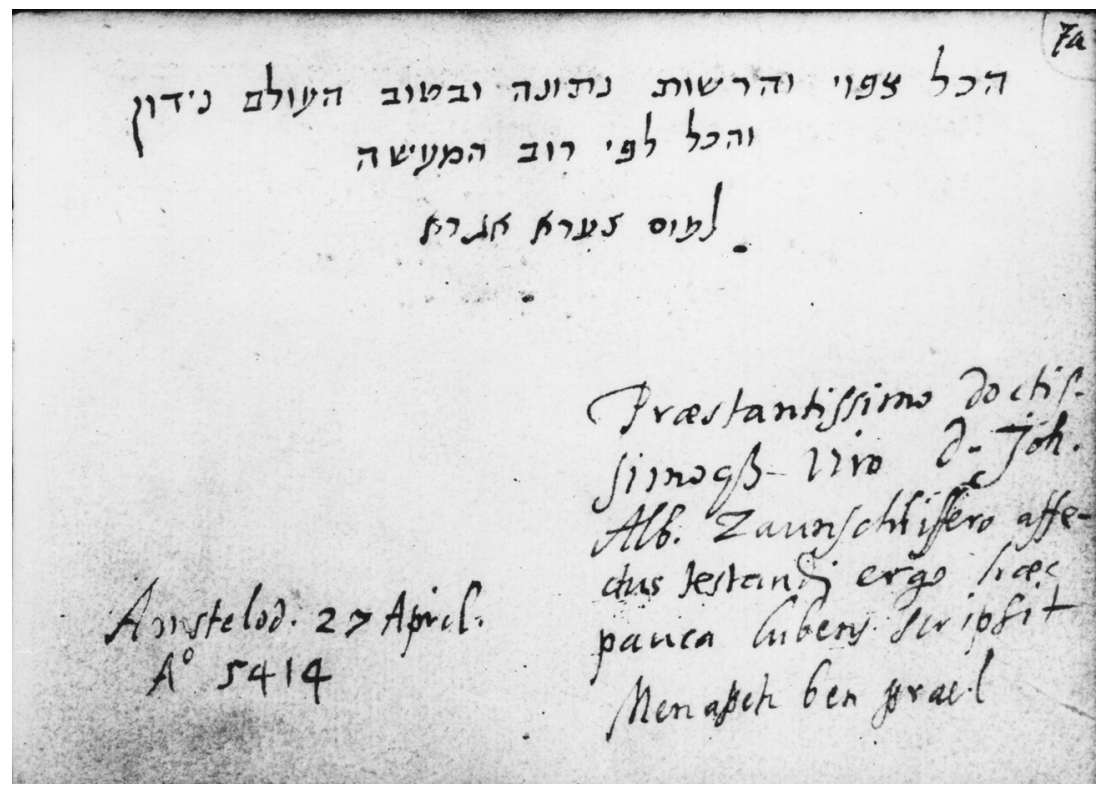

Inscription for Johan Albert Zaunschliffer (courtesy: University Library, Amsterdam)

\section{הכל צפוי והרשות נתונה ובטוב העולם נידון

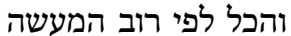 לפום צערא אגרא המשרא}

Amstelod. 27 April. $A^{\circ} 5414$
Praestantissimo doctissimoque viro D. Joh. Alb. Zaunschliffero affectus testandi ergo haec pauca lubens scripsit Menasseh ben Israel

[Hebr.] 'All is foreseen, but freedom of choice is given; and the world is judged by grace, yet all is according to the excess of works' (Pirqe Avot 3.16). ${ }^{25}$

[Aram.] 'According to the suffering so is the reward' (Pirqe Avot 5.23). ${ }^{26}$ [Dedication] For the outstanding, most learned mister Johan Albert Zaunschliffer, Menasseh ben Israel with pleasure wrote these few words as a testimony of his affection.

\footnotetext{
${ }^{25}$ Transl. Danby, The Mishnah, 452.

${ }^{26}$ Ibid., 458.
} 
Benedek Árkosi, like his younger friend István Pauli, descended from a Unitarian family in Transylvania. Together they read Philosophy and Theology in Frankfurt/Oder, Leyden, and elsewhere. On his return in 1654, he was appointed professor of Theology at the Unitarian College of Kolozsvár. He died in 1661.27

Árkosi's album amicorum is kept in the Library of the Protestant Theological Institute, Cluj-Napoca (Romania) [Ms. 106]. Among the other inscribers are the Remonstrant Stephanus Curcellaeus (inscription dated May 13, 1654) and the Amsterdam Mennonite minister Galenus Abrahamsz (1622-1706, inscription dated May 14, 1654). Menasseh's inscription is on fol. $145 \mathrm{r}$.

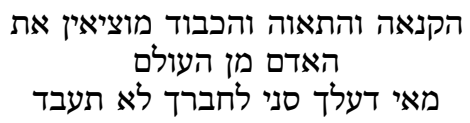

Amstelodami

15 Maij. $A^{\circ} 5414$
Ornatissimo generoso atque litteratissimo viro D. Benedicto Arcossi affectus testandi ergo pauca haec lubens scripsit Menasseh ben Israel

[Hebr.] 'Jealousy, lust, and ambition put a man out of the world ' (Pirqe Avot 4.21). ${ }^{28}$

[Aram.] 'What is hateful to you, do not to your neighbour' (Shabbath 31a). ${ }^{29}$

[Dedication] For the most talented, generous and lettered mister Benedek Árkosi, Menasseh ben Israel with pleasure wrote these few words as a testimony of his affection.

${ }^{27}$ Kathona, 'Erdélyi unitárius', 33-34, Szabó and Tonk, Erdélyiek egyetemjárása, 32 (nr. 308).

28 Transl. Danby, The Mishnah, 455.

29 Transl. Freedman, Babylonian Talmud. 


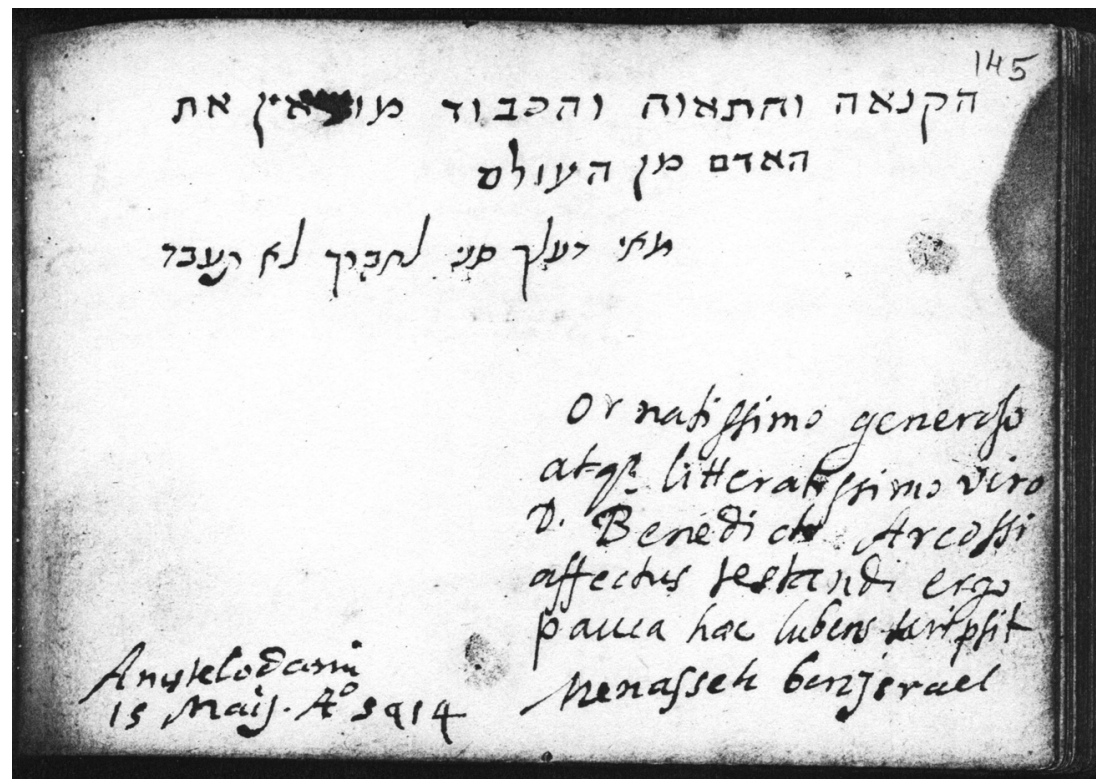

Inscription for Benedek Árkosi (courtesy: the Library of the Protestáns Teológiai Intézet, Cluj-Napoca)

Inscription Dedicated to Fohann Zollikofer, Amsterdam, August 10, 1655

Johann Zollikofer was born on December 29, 1633. He read Philosophy and Theology first in Zurich and later on in Basle, where he obtained the degree of Magister on November 29, 1651. He became a Reformed minister, in St. Gallen (Switzerland) and eventually in Herisau where he died on April 24, 1692. ${ }^{30}$ In 1655 Zollikofer, a friend of Johann Buxtorf the younger (1599-1664), ${ }^{31}$ travelled through France to Amsterdam where he stayed for a while. His album amicorum is kept in the Vadianische Sammlung der Ortsbürgergemeinde St. Gallen [VadSlg Ms. 92a]. Among the other inscribers is John Milton, whom Zollikofer, like Menasseh, met in $1656 .{ }^{32}$ Menasseh's inscription is on fol. 172 r.

${ }^{30}$ H.M. Stückelberger and W. Hirzel, eds., Die Pfarrerschaft der evangelisch reformierten Landeskirche beider Appenzell, s.l. (1991) 25. Cf. Jöcher, Allgemeines Gelehrten-Lexicon, IV, $2221 \mathrm{f}$.

31 Roth, A Life, 165.

32 Cf. above, Arnold. 


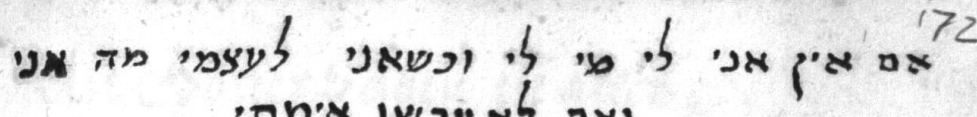

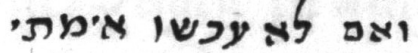

Spes et paliontia

Amptel. An squs. x. Ang.

Virtute doctrinagl noGififimo viro, Dohuni

- Foliceffero in Jignum oerevoti affechic panca lae nbens sevibebat

Menalseh benjsrad

Inscription for Johann Zollikofer (courtesy: Vadianische Sammlung, St. Gallen)

\section{אם אין אני לי מי לי וכשאני לעצמי מה אני ואם לא עכשו אימתי ליעצי}

Spes et patientia

Amstel. An. 5415.

Virtute doctrinaque nobilissimo viro, D. Fohanni Zolicoffero in signum benevoli affectus, pauca haec lubens scribebat

X. Aug.

Menasseh ben Israel

[Hebr.] 'If I am not for myself who is for me? and being for mine own self what am I? and if not now, when?' (Pirqe Avot 1.14). ${ }^{33}$

[Lat.] Hope and patience. ${ }^{34}$

[Dedication] For mister Johann Zollikofer, most noble through virtue and learning, Menasseh ben Israel with pleasure wrote these few words as a token of his well-wishing affection.

\footnotetext{
33 Transl. Danby, The Mishnah, 447.
}

${ }^{34}$ Cf. above, Gerhard. 